\title{
The Effect of ASEAN Economic Integration on Foreign Direct Investment
}

\author{
Normaz Wana Ismail \\ University Putra Malaysia \\ Peter Smith \\ University of Southampton \\ Maurice Kugler \\ University of Southampton \\ Harvard University
}

\begin{abstract}
The primary concern of this study is to highlight AFTA's roles in increasing ASEAN countries' attractiveness for FDI from members and non-members, noting that the agreement has been followed by many packages to enhance FDI flows into the region. The time period cover in this study is after the AFTA has been implemented (1995 to 2003). The gravity model is employed in this study in the analysis based on cross section and panel data analysis. There are two main effects are considered in this study, namely the effects of REI on intra-regional FDI flows and on extra-regional FDI flows. The major finding of this study is the ASEAN5 invest in each other less than they invested in the new ASEAN members. The empirical results from extra-regional-FDI revealed that the European

*Normaz Wana Ismail(Corresponding author): Department Economics, Faculty of Economic and Management, University Putra Malaysia, 43400 UPM Serdang, Selangor, Malaysia, Tel: 60389467708, e-mail: nwi@econ.upm.edu.my, Peter Smith: Economic Division, School of Social Sciences, University of Southampton, SO17 IBJ Southampton, United Kingdom, e-mail: peters@soton.ac.uk, Maurice Kugler: Department of Economics, Wilfrid Laurier University, 75 University Avenue West, Waterloo, Ontario, Canada N2L 3C5, Tel: 519884 0710(ext.4162), e-mail: mkugler@wlu.ca.

(2009-Center for International Economics, Sejong Institution, Sejong University, All Rights Reserved.
\end{abstract}


countries increase investment in ASEAN than any other region in the sample. Moreover, further investigation also found that the USA and Japan invested more in ASEAN5 than in the new ASEAN members.

- JEL Classification : F000, F150, F210

- Key Words: ASEAN, AFTA, foreign direct investment, gravity model

\section{Introduction}

Many previous studies on Regional Economic Integration (REI) have primarily focused on trade creation and trade diversion as proposed by Viner (1950). The relationship between REI and FDI became a concern after the formation of the EEC in the 1960s. Recently, studies specifically focusing on FDI-REI relationship have been given more attention particularly in developing countries such as Southeast Asian countries, East Asian countries and Latin America. However, the predictions of existing theoretical frameworks are ambiguous with regards to the relationship between REI and FDI. According to Yeyati, Daude and Stein (2002), the impact of REI on bilateral FDI depends on whether the source and host countries are members of an REI. For instance, FDI flows from the United States to Canada and Mexico will have different effects than flows from France. In the same way, FDI flows from the United States to NAFTA's member will be affected differently than flows to other countries belonging to other regional groups. In addition, FDI flows also depend on other characteristics. ${ }^{1}$

However, many researchers (e.g., Blomstrom \& Kokko, 1997; Yeyati et. al., 2002) also agree that the impact of REI on FDI depends on the structure or motive of FDI-specifically, whether it is horizontal or vertical FDI. Horizontal FDI (HFDI) occurs when a firm relocates production abroad because it is cheaper to produce in a foreign country rather than export their domestic production and pay tariffs. Generally, such firms produce homogenous goods with multiple production facilities, and each production facility serves its domestic market. Vertical FDI occurs when a firm locates its production process and facilities in countries with the required human capital and infrastructure facilities and take advantage of the international differences in factor prices. Some production involves several stages, each carried out in a different country. A firm's production serves not only its

\footnotetext{
${ }^{1}$ Many empirical evidence supports that having cheap resources, excellent communication and infrastructure, macro and political stability, and skilled workers are also encourage FDI into a country.
} 
domestic market, but also foreign markets. According to Markusen and Venables (1998) and Markusen et al. (2000), if countries differ in relative factor endowments and trade costs are low then vertical FDI dominant. But when factor costs and size differences between two countries are marginal, trade cost are medium to high thus initiating more horizontal FDI.

Although the traditionally theory views that trade and FDI as substitutes; however, some researchers agree that trade and FDI can be both substitutes and complementary (Carves, 1996). This may contribute to the ambiguous theoretical framework of REI and FDI. In the case of tariff jumping strategy, the formation of a free trade area reduces transaction cost and discourages a firm to produce in multiple countries. Exporting to the countries within the free trade area is cheaper than investing suggesting that FDI and trade are substitutes. However, empirical evidence also shows that FDI and trade are complementary (e.g., Graham, 1996; Mauro, 2000; Brenton \& Mauro, 1999; Marchant et al., 2002; Aninian et al., 2007). In the case of vertical FDIs, when a firm produces differentiated products, the link between trade and FDI are more complementary. Trade and FDI are also complements when a firm locates its production in a labour-abundant foreign country then re-exports s the goods to its home country (Motta \& Norman, 1996). In other words, a reduction of trade barriers will therefore enhance particularly vertical FDI into host countries.

Another issue related to REI and FDI is the sets of rules of origin which can be part of foreign investor's decision to invest in a free trade area. Members of REI need to set the rules of origin to determine the eligibility of products to receive preferential access such as zero tariffs and to avoid trade deflection when products from non members are redirected via free trade members to avoid custom duty. The market is integrated if products that satisfy rules of origin are freely traded within the free trade area (Ishikawa et al., 2007). AFTA applies a single method to determine the rules of origin compared to three methods required by the EU and the USA. Thus, foreign investors can take advantage in free trade area that has less complex rules of origin.

The purpose of this study is to examine the impact of regional economic integration with particularly attention to AFTA on foreign direct investment. Many previous studies have investigated the determinants of foreign direct investment and the effects of REI on trade. However, the relationship between REI and FDI, with a particular focus on the ASEAN Free Trade Area (AFTA), has been largely unexplored. The analyses focus on the effect of the implementation of the AFTA in 
1992 and the subsequent establishment of the ASEAN Industrial Cooperation (AICO) in 1996 and the ASEAN Investment Area (AIA) in 1998. The AICO scheme is ASEAN's industrial cooperation programme intended to promote joint manufacturing industrial activities between ASEAN-based companies. The main objectives of this scheme are to enhance ASEAN's industrial production, attract investment from ASEAN and non-ASEAN sources and intensify intra-ASEAN trade. The AIA scheme aims to provide an environment that facilitates free flow of direct investment, technology and skilled professionals. The AIA arrangement also provides opportunities for investors to adopt regional business strategies and establish network operations in the region.

As far as FDI is concerned, thirty years ago, ASEAN countries were worried about opening their market to allow foreign investment, which was expected to affect local economies. All ASEAN members except Singapore had adopted restrictive regulations to control FDI firms in order to alleviate the harmful effects of FDI. However, attitudes toward FDI shifted by the late 1970s due to the debt crisis of 1985 and the evocation of Newly Industrial Economies (NIEs) ${ }^{2}$ via changes in investment incentives to promote FDI. In the mid 1980s, most ASEAN countries switched from inward to outward strategies, which coincided with a large influx of foreign direct investment from Japan and NIEs. ${ }^{3}$ Net FDI inflows into ASEAN in 1972 were only US\$539million, however there increased tremendously in 1982 by more than $500 \%$ which amounted to US\$343095.85 million. In 1993 ,

Figure 1. Total FDI Inflows to ASEAN Countries (1970-2003)

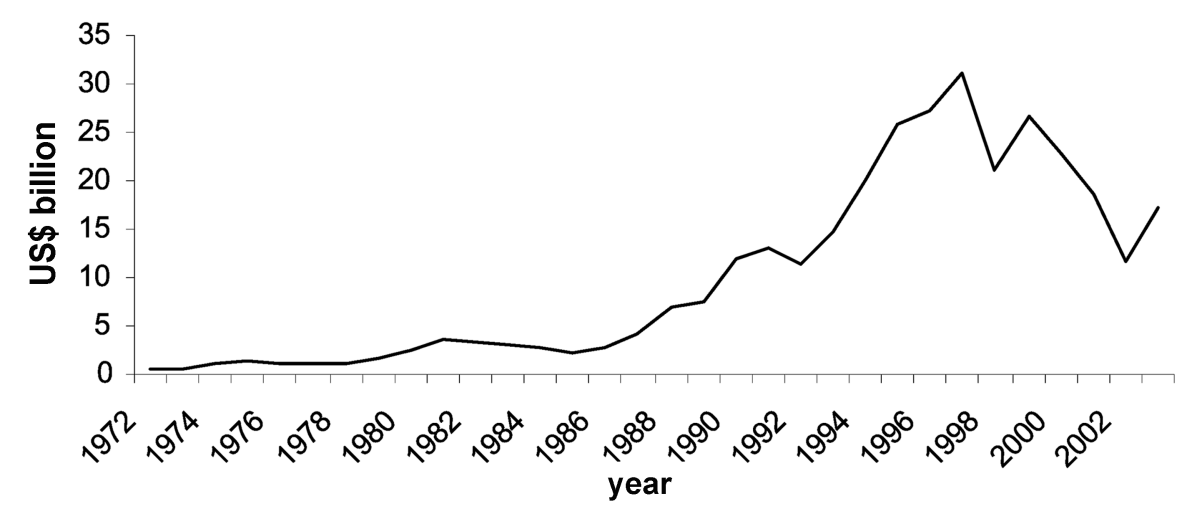

Source: World Development Indicators

${ }^{2}$ NIEs represent countries such as South Korea, Singapore, Taiwan and Hong Kong

${ }^{3}$ Japan and NIEs sought to relocate their labor-intensive operation overseas. 
the amount of FDI inflows was registered as US\$14.737 billion and amounted to US $\$ 18.4$ billion in 2003 which increased by $22 \%$ over a decade

Figure 1 shows the evolution of FDI into ASEAN countries from 1970 to 2003. The trend of FDI flows was very low through out 1970s and mid 1980s. However, FDI flows to ASEAN members appears to a positive trend before rocketing in 1993, the year that ASEAN Free Trade Agreement was implemented. This shows a continuous increase in the inflows until the financial crisis that affected most ASEAN countries in 1997/1998. FDI inflows decrease by about $23 \%$ during the crisis. The decline was attributed to lower inflows of investment from some of the ASEAN's main sources of FDI due to economic situation specific to these countries particularly from Japan, South Korea and intra-ASEAN investments. The "time-lag effect" of the financial crisis and the weakened corporate sector in ASEAN has been the main reasons for the significant decline in intra-regional investments.

In the light of this development, the primary concern of this study is to highlight AFTA's roles in increasing ASEAN countries' attractiveness for FDI from members and non-members, noting that the agreement has been followed by many packages to enhance FDI flows into the region. Moreover, AFTA can be as an example to the south-south agreement or free trade agreements signed among developing countries. The time period cover in this study is after the AFTA has been implemented (1995 to 2003). There are two main effects are considered in this study, namely the effects of REI on intra-regional FDI flows and on extraregional FDI flows. First, the intra-regional FDI flows are likely to reduce when the REI area has primarily horizontal FDI or tariff-jumping strategy. Foreign firms that were initially attracted to a country can now produce and supply from cheaper production bases in other countries within the region. Furthermore, free trade amongst member countries makes exporting relatively cheaper vis-à-vis FDI as a way to serve the regional market (Blomstrom \& Kokko, 1997). However, for a firm which invests in the form of vertical FDI, a reduction of trade barriers would lead to increased FDI as it becomes easier to export the finished product back to the home country or elsewhere in the region. The second effect of REI is on extraregional FDI flows. A reduction of tariff protection within the free trade area will increase flows of both horizontal and vertical FDI from the rest of the world. In addition, according to Blomstrom et al (1998), FDI flows from non-member countries are likely to rise if the average level of protection of the rest of the world increases, or if the formation of REI raises fears of future protection. 


\section{Literature Review}

This section is divided into two parts - theoretical and empirical literature. The theoretical section discusses approaches to modelling FDI in an REI context, and the empirical literature section discusses evidence on the relationship between FDI and REI.

\section{A. Theoretical Literature}

Several studies explain the relationship between REI and FDI. Motta and Norman (1996) analyze the effects of economic integration on oligopolist multinationals in a three country setup: two integrating (host) countries that are members of an RIA, and a source country external to the RIA. The effects of market accessibility (the extent of a reduction in intra-regional tariff and non-tariff barriers to trade) and the impact of individual country size are distinguished. Their results are consistent with the existence of parallel trade and FDI flows. In particular, they show how economic integration, by improving market accessibility, induces outside firms to invest in the integrated regional bloc, generating intraregional platform FDI from the external country, ultimately leading to increased trade volumes between the integrating countries.

Another interesting study explore by Neary (2002) on the effects of trade liberalisation and inward investment. Findings reveal that tariff jumping motive encourages plant consolidation. He also notes that firms undertake export-platform motive, when it finds more benefits for FDI in an FTA rather than export to countries in the FTA. Internal tariff reduction increases competition from domestic firms and dilutes both the tariff jumping and export platform motives. Conversely, Heinrich and Konan (2000) examine how preferential trading agreements affect MNCs' incentives to invest in integrating countries and find that the extent to which MNCs will invest depends on the size of the barriers to trade (transportation costs). Induced welfare effects are also found to be beneficial for the integrating countries. They consider a partial-equilibrium three-country world in which two countries join a PTA and the third country is the MNC parent country. On a similar issue, but with a different setup, Donnenfeld (2003) uses an n-country analysis of trade barriers to examine the impact of the emergence of regional blocs on the patterns of inter-bloc and intra-bloc trade when firms have the option to engage in FDI. He finds that, for exogenously given external tariffs, and when firms have the option to engage in FDI, all inter-bloc trade may cease-complete trade diversion 
that is replaced by inter-bloc FDI investment creation. He also finds that the formation of two regional blocs enhances the welfare of all countries.

\section{B. Empirical Literature}

Available empirical studies tend to relate intra and extra regional FDI into the region. Effects of REI on FDI vary between different regional groups, countries and industries, and country characteristics also attract foreign investment. Furthermore, studies on the relationship between REI and FDI, either internal or external FDI, primarily focus on the experiences of the European Community (EC). For instance, Egger \& Pfaffermayr (2003) study the impact on bilateral European FDI relations of three different events in the EU integration process during the 1990s: the Single Market Program (SMP), the 1995 enlargement and the Europe Agreements between the EU and the CEEC. Findings reveal that anticipation effects on FDI typically take place between the announcement and the formal establishment of the integration. FDI does not increase before the official announcement of an integration step, but with the formal completion. However, Dunning (2000) found that both intra and extra European Community FDI have been stimulated after the Internal Market Program (IMP) in Europe was launched in 1985. Findings also show that FDI growth and trade growth are complementary. Similarly, Pains \& Lansburry (1997) show that intra-regional FDI increased in the UK and Germany after the IMP was implemented. They also find evidence of investment diversion from the US and Austria to the benefit of European Community.

There is also one study that undertakes an empirical investigation of the effects of the EU enlargement process in the Central Eastern European Countries (CEEC). Clausing and Dorobantu (2005) examine the ability of CEECs to attract FDI during the first decade of transition. They find empirical support that market size and cost factors are the determinants of MNCs' location decision within the region. In addition, the effects of EU accession announcement also shows a statistically significant effect on FDI in the CEEC candidate countries. Bevan et al. (2001) also found that the announcement of the progress in EU accession directly affect FDI flows from 18 established market economies to 11 transition economies in 1994 to 1998. Political announcements concerning the timetables for EU admission also cause a rise in the level of FDI.

On the other hand, Balasubramanyam et al. (2002), studying the EU and NAFTA does not find that the presence of REI or RIA to determine the direction of 
bilateral FDI flows. Instead, economic characteristics such as population, income, market-size and distance are the main determining factors in both host and source countries. Buch et al. (2003) find that economic integration and the transition per se do not increase FDI flows from Germany into the CEEC during the region's accession period. There was a substantial amount of German FDI into the accession states but the FDI is distribution follows an uneven pattern. German MNCs are also found to select host country based on factors such as factor endowment, the legal environment and distance.

However, many recent studies have focused more attention on the regional economic integration in North America. Examples include Blomstrom \& Kokko (1997) and Blomstrom et al. (1998). Conceptually, in a purely descriptive analysis, a positive impact of REI on FDI can occur when regional integration agreements coincide with domestic liberalisation and macroeconomic stabilisation in the member countries. They found that North-North agreements like CUSTFA do not appear to cause any radical change in the inflows of FDI to Canada. However, the NAFTA North-South agreement has created new opportunities for domestic and foreign investors in Mexico as well as in Canada. There is also a significant increase in inward FDI from outside of the NAFTA region. For instance, Waldkirch (2001) investigates the impact of NAFTA on inward FDI in Mexico and finds that FDI has substantially increased in Mexico, mostly from its intra-regional partner's - Canada and the US. The North American experience suggests a more modest impact of regional trade agreements on intra-regional trade creation and extra regional FDI stimulation than that in the earlier stages of the EU integration.

Regarding south-south agreements, those that involve agreements between developing nations show mixed findings on FDI. For instance, Jaumotte (2004) finds RTA market size to positively affect FDI, but there is a negative partial correlation between FDI received by RTA countries. He concluded that the investment received from non-RTA possibly reflected investment diversion effects of FDI from non-RTA to RTA country. However, the results of Blomstrom and Kokko (1997), who study the effects of Mercosur in Latin America, indicate that a strong investment expansion has coincided with the integration process. In fact, the inflows of FDI are not equally distributed to all participating countries, with Argentina and Brazil receiving particularly strong FDI flows. This is, however, claimed to be a result of stabilisation programmes in place there, rather than a direct consequence of regional integration.

In relation to FDI and ASEAN, Bende-Nabende et al. (2001) investigate 
whether the ASEAN Preferential Trade Agreement (APTA) from 1970 to 1996 significantly affected FDI into the region. Findings found a positive effect in the cases of Malaysia, Singapore and Thailand, but a negative one for the Philippines and Indonesia. Mirza and Giroud (2004) interviewed 113 companies in Singapore, Malaysia, Thailand, Vietnam and Cambodia, and find that flows of FDI to the ASEAN region have increased, particularly after the signing of AFTA. However, the experience of individual economies differs widely. They find that many MNCs located their centre or headquarters in Singapore, research and development in Malaysia and Thailand and basic assembly type operations in Vietnam and Cambodia.

\section{Empirical Methodology}

\section{A. Source of Data}

Data on bilateral FDI flows are derived from the ASEAN FDI Statistical 200405 covering the period from 1995 to 2003 . To our knowledge, this is the only database that covers bilateral FDI flows that include all ASEAN countries. The dataset covers 18 source countri ${ }^{4}$ es and 9 host countr ${ }^{5}$ ies which include all ASEAN members except Cambodia. The choice of source countries is based upon the fact that some of them are major sources of world FDI flows, such as the USA, Japan and European countries, whilst other investors are from emerging countries. The GDP, per capita GDP, export and import are from the World Bank Indicators. Meanwhile, the distance which was calculated was based on the great circle formula using latitudes and longitudes of the most important city (in terms of population) accessed from Centre D'etudes Prospective Et D'informations Internationals (CEPII). An alternative proxy for distance costs common language and common border are also accessed from CEPII.

\section{B. Gravity Model}

Gravity model has been applied in various empirical research including migration, patent rights, international trade and foreign direct investment. The

\footnotetext{
${ }^{4}$ Source countries are Japan, China, Hong Kong, Taiwan, South Korea, Singapore, Malaysia, Indonesia, the Philippines, and Thailand, the Unites States of America, Canada, Australia, New Zealand, France, Germany, the United Kingdom and the Netherlands.

${ }^{5}$ Host countries are ASEAN countries - Malaysia, Indonesia, Thailand, the Philippines, Singapore, Laos, Myanmar and Vietnam.
} 
gravity model has been used to explain bilateral trade and can be transposed to bilateral FDI (Eaton \& Tamura, 1996). The model is not only reliable and applicable but also justifiable in terms of trade theories, from the traditional theories such as the Ricardian Framework (Eaton \& Kortum, 1997) and the Heksher-Ohlin model (Deardorff, 1998; Evenett \& Keller, 1998; Feenstra et al., 2001 ) to the new trade theories such as imperfect competition (Anderson, 1979; Bergstrand 1985, 1989) and economies of scale (Helpman and Krugman, 1985). The model has been improved in terms of econometric issues such as the use of panel estimation against cross section and the inclusion of country characteristics in the Fixed Effect Model to control heterogeneity problems. The model is recently applied in the relationship between REI and FDI and the determinants of FDI across countries and regions (see Carlo Almonte, 1998); Brenton et al., 1999; Bevan et al., 2001; Balasubramanyam et al., 2002; Yeyati et al., 2002; Buch et al., 2003).

Following Yeyati, Stein and Daude (2002), both host and source country factors are included in the estimates. They estimated the effect of economic integration and FDI within the same REI ${ }^{6}$, however, this study focuses on the effects of the economic integration of ASEAN and FDI. Analyses for this study are in two stages. The first estimation compares the cross section versus panel approach. The estimation includes the basic gravity variables, log of Distance and log of GDP for source and host countries, trade openness, common border, common language and the log for GDP per capita for both source and host countries, and the fixed effects model for the bilateral FDI from ASEAN to the individual host country-all ASEAN members. The second stage estimates the effect of extra-regional-FDI is based on five source regional group namely ASEAN-5, East Asia, Europe, North America and Australia-New Zealand. Moreover, the refined model also includes bilateral FDI from source group countries to Singapore, the four original ASEAN and the new ASEAN members.

The dependent variable is bilateral FDI inflows into ASEAN countries. However, many observations whose value is zero cannot simply be excluded because they may contain important information. Therefore, to avoid losing observations which represent about 20 percent of the sample, following Eichengreen \& Irwin (1995) and Yeyati, Stein \& Daude (2002), the dependent

${ }^{6}$ They studies on 20 source countries and 60 host countries for period from 1982 to 1999 , which covers general effect of REI and FDI. 
variable is $\log (1+\mathrm{FDI})$, instead of the $\log$ of FDI. ${ }^{7}$ The full specification is presented in (1).

$$
\ln (1+F D I)_{i j t}=\alpha+\beta Y_{i j t}+\mu X_{i j}+\tau R E I-1+\sigma R E I-2+\varepsilon_{i j t}
$$

where

$$
\begin{aligned}
& \alpha=\eta+\xi_{t}+\lambda_{i}+\gamma_{j}+\delta_{i j} \\
& Y=\left(\ln G D P_{i t}, \ln G D P_{j t}, \ln P G D P_{i t}, \ln P G D P_{j t}, \ln O P E N_{j t}\right)
\end{aligned}
$$$$
X=\left(\ln D I S T_{i j}+L A N G_{i j}+B O R D E R_{i j}\right)
$$

$\ln (1+\mathrm{FDI})_{i j t}: \quad$ the $\log$ of FDI inflows from source country $(i)$ to host

$P G D P_{i}, P G D P_{j t}: \quad$ gross domestic product per capita, proxy for the level of development

$O_{P P N}$ : $\quad$ the sum of export and import ratio to GDP for the host country,

$D I S T_{i j t}: \quad$ is the distance between capital cities of source country $\mathrm{i}$ and host country $\mathrm{j}$ in kilometres, proxy for transaction cost,

$L A N G_{i j}$ : $\quad$ Dummy variable to control for two countries that share a common language,

$B O R D E R_{i j}$ : $\quad$ Dummy variable to control for two countries that share a common border,

REI-1: $\quad$ Dummy variable, value of one if two countries are ASEAN5

(Malaysia, Indonesia, the Philippines, Thailand and Singapore), ASEAN4 (Brunei, Laos, Myanmar and Vietnam); or otherwise zero,

REI-2: $\quad$ Dummy variable, value of one if source country $(i)$ is ASEAN

(Malaysia, Indonesia, the Philippines, Thailand and Singapore); East Asia (Japan, South Korea, China, Taiwan, Hong Kong), North America (United States of America and Canada); AUNZ (Australia and New Zealand); and Europe (France, Germany, United Kingdom and Netherlands) or otherwise zero.

\footnotetext{
${ }^{7}$ Since the $\log$ form of zero does not exist.
} 
The intercept has five parts: $\eta_{0}$ is a constant term which is common to all years and country pairs, $\lambda_{i}$ and $\gamma_{j}$ are host and source countries effects respectively which control for country characteristics, $\delta_{i j}$; is a bilateral FDI effect to capture the interaction effects between two countries and $\xi_{t}$; is the time effects to capture business cycle and common to all countries in the sample. The disturbance term, $\varepsilon_{i j t}$, is assumed to be normally distributed with zero mean and constant variance for all observations and captures any other external shocks that may affect bilateral FDI between the countries.

GDP and PGDP for both source and host countries captures market size and the level of development, and are expected to have a positive relationship with FDI. Openness may have a positive sign because more open economies will associated with higher FDI inflows, when FDI and trade are complement. This also can be a proxy for free trade agreement if the estimation looking at the within regional effects as AFTA reduces tariff barrier among the members of ASEAN countries. Distance as a proxy of transportation cost is expected to be negatively related with FDI. Common border and common language are expected to be positively related with FDI, especially for intra-regional FDI since foreign investors from neighbouring countries may take the opportunity to invest in a country which shares a common culture, language or border.

\section{Some Econometric Consideration}

The use of a random effect model or a fixed effect model has raised attention in the gravity model estimation. A random effect model is appropriate to estimate typical trade flows by randomly drawn sample of trading partners particularly from a larger population. However, the fixed effect model is the better choice to estimate trade between an ex ante predetermined selection of nations (Egger, 2000). In the case of the absence of any correlation between observable and panel specific error terms, the random effect approach is preferred. Implicitly, the fixed effect model assumes that all explanatory variables are correlated with the unobserved effects or the specific error term that eliminates this correlation within the transformation. Matyas (1997) and Egger $(2000,2002)$ suggest using the Hausman test ${ }^{8}$ in choosing the fixed effect model or the random effect model. The null hypothesis of the test is there is no correlation between individual effects and the explanatory variables. This implies that both random and fixed effects are consistent but only

${ }^{8}$ Hausman(1978) suggested a test to check whether the individual effects are correlated with the regressors 
the random effect is efficient. Meanwhile the alternative hypothesis states that the individual effects are correlated with the explanatory variables, implying that only the fixed effect approach is consistent and efficient.

\section{Empirical Results}

\section{A. Effects of Intra-ASEAN FDI}

Prior the estimation, the Hausman test $(p$ value $=0.0041)$ shows that the $p$ value is less than 0.05 which is significant. This implies that the null hypothesis that Random Effect Model which consistent and efficient is rejected. Therefore, the Fixed Effect Model is preferred model and will be used in this study.

Table 1 presents the estimation effects of ASEAN on intra-ASEAN FDI based on panel data from 1995 to 2003 . Column (1) reports the estimation including gravity variables and reveals that all variables are significant and have the correct sign, with the exception of border, which is positive but insignificant. As predicted, both coefficients of $\ln G D P$ and $\ln G D P$ per capita for either host or source are positive and significant suggesting that as the market size and the income per capita for both source and host countries increases, the flow of FDI from source to host country increases as well. By contrast, the coefficient of distance is negative and significant, implying that lower transaction cost of the host and source countries leads to more FDI inflows into the host country. Language is positive and significant indicating that when source and host countries share a common language, more FDI is expected to flow into the host country. However, the border coefficient is insignificant, which implies that a common border is not an important factor in attracting more FDI into the countries.

In column (2), variable of $\ln O P E N$ is included in the regression as a proxy for trade openness which the estimated coefficient is positive and highly significant. This result may suggest that trade relationship with FDI is positive as a sign of complementarities. As 10 percent increase in trade, the expected FDI flows increase is about 4.5 percent. The next following estimation (column 3 to 5) shows the results when the dummies for intra-regional FDI in ASEAN5 and other ASEAN countries are included. All gravity variables including Border are correctly signed and significant. However, in this estimation the time effects are included to capture the trend of FDI within the time period. The dummy coefficient for intra regional FDI in ASEAN5 is positive but insignificant. This implies that the 
investment flows within ASEAN5 are not more or less than would be predicted by other independent variables. However, dummy coefficient for intra regional FDI between ASEAN5 and the other four ASEAN members (Brunei, Laos, Myanmar and Vietnam) is positive and significant. These results suggesting that while membership in free trade area increases inflows from ASEAN5 to new members, however those flows do not appear within the original ASEAN5

There is possibility that after the formation of AFTA in 1992, the introduction of investment packages such as AICO in 1996 and AIA in 1998 benefited Brunei and the three new members of ASEAN as the schemes aim to attract investment from ASEAN and non-ASEAN sources and intensify intra-ASEAN trade. Bilateral FDI flows from ASEAN5 to ASEAN4 have grown 95 percent $^{9}$ faster than intra FDI in

Table 1. Gravity Estimation on Panel of 1995-2003

\begin{tabular}{|c|c|c|c|c|}
\hline & (1) & (2) & (3) & (4) \\
\hline $\ln G D P$ source & $\begin{array}{c}0.466^{\text {*** }} \\
(11.86)\end{array}$ & $\begin{array}{c}0.450^{* * *} \\
(11.28)\end{array}$ & $\begin{array}{l}0.513^{* * *} \\
(13.36)\end{array}$ & $\begin{array}{l}0.516^{* * *} \\
(13.22)\end{array}$ \\
\hline $\ln G D P$ host & $\begin{array}{l}0.177^{* * *} \\
(2.64)\end{array}$ & $\begin{array}{l}0.194^{* * *} \\
(2.91)\end{array}$ & $\begin{array}{l}0.179^{* * *} \\
(2.89)\end{array}$ & $\begin{array}{l}0.177^{* * *} \\
(2.85)\end{array}$ \\
\hline $\ln P G D P$ source & $\begin{array}{c}0.607^{* * *} \\
(14.63)\end{array}$ & $\begin{array}{l}0.593^{* * *} \\
(14.15)\end{array}$ & $\begin{array}{l}0.715^{* * *} \\
(17.52)\end{array}$ & $\begin{array}{l}0.718^{* * *} \\
(16.80)\end{array}$ \\
\hline $\ln P G D P$ host & $\begin{array}{l}0.172^{* * *} \\
(4.53)\end{array}$ & $\begin{array}{l}0.164^{* * *} \\
(4.27)\end{array}$ & $\begin{array}{l}0.184^{* * *} \\
(4.98)\end{array}$ & $\begin{array}{l}0.185^{* * *} \\
(4.92)\end{array}$ \\
\hline $\ln O P E N$ host & $\begin{array}{l}0.443^{* * *} \\
(7.76)\end{array}$ & $\begin{array}{l}0.447^{* * *} \\
(7.86)\end{array}$ & $\begin{array}{l}0.535^{* * *} \\
(10.03)\end{array}$ & $\begin{array}{l}0.536^{* * *} \\
(10.06)\end{array}$ \\
\hline $\ln D I S T$ & $\begin{array}{l}-0.914^{* * *} \\
(-11.74)\end{array}$ & $\begin{array}{l}-0.927^{* * *} \\
(-11.79)\end{array}$ & $\begin{array}{l}-0.724^{* * *} \\
(-9.01)\end{array}$ & $\begin{array}{l}-0.719^{* * *} \\
(-8.82)\end{array}$ \\
\hline BORDER & $\begin{array}{l}0.084 \\
(1.17)\end{array}$ & $\begin{array}{l}0.078 \\
(1.09)\end{array}$ & $\begin{array}{l}0.231^{* * *} \\
(3.10)\end{array}$ & $\begin{array}{l}0.233^{* * *} \\
(3.09)\end{array}$ \\
\hline Language & $\begin{array}{l}0.473^{* * *} \\
(6.14)\end{array}$ & $\begin{array}{l}0.482^{* * *} \\
(6.16)\end{array}$ & $\begin{array}{l}0.382^{* * *} \\
(5.05)\end{array}$ & $\begin{array}{l}0.379^{* * *} \\
(10.06)\end{array}$ \\
\hline Intra ASEAN5 & & $\begin{array}{l}-0.203^{\text {*** }} \\
(-2.74)\end{array}$ & & $\begin{array}{l}0.029 \\
(0.37)\end{array}$ \\
\hline ASEAN5 to new & & & $\begin{array}{l}0.668^{* * *} \\
(10.53)\end{array}$ & $\begin{array}{l}0.676^{* * *} \\
(9.82)\end{array}$ \\
\hline constant & $\begin{array}{l}-10.328^{* * *} \\
(-21.76)\end{array}$ & $\begin{array}{l}-10.235^{* * *} \\
(-21.57)\end{array}$ & $\begin{array}{c}-13.139^{* * *} \\
(-24.27)\end{array}$ & $\begin{array}{c}-13.185^{* * *} \\
(-23.46)\end{array}$ \\
\hline observation & 1,265 & 1,265 & 1,265 & 1,265 \\
\hline$R^{2}$ & 0.4948 & 0.4962 & 0.5261 & 0.5261 \\
\hline
\end{tabular}

Notes: $* * *, * *$ and $*$ denote $1 \%, 5 \%$ and $10 \%$ level of significance, respectively. The figures in parentheses are the $t$-statistics

$\overline{9}\left(\exp { }^{0.668}-1\right) * 100=95 \%$ 
ASEAN5 between 1995 and 2003. Further investigation of the effect of intraregional FDI by the introduction of a bilateral dummy for FDI from the five original ASEAN5 members and the other ASEAN4 (result not listed in the table) confirms that all FDI flows from Indonesia, Malaysia, the Philippines, Thailand and Singapore to the other ASEAN4 are positive and significant. However, the coefficient for the original ASEAN members remains insignificant.

Table 2 presents the estimation of the gravity equation for each year. Overall, the coefficients of the market size and income per capita in source countries are positive and significant for all years. Other results are quite similar with the panel results and consistent throughout the year. The dummies for intra-ASEAN FDI are insignificant throughout the years except in 2002 and 2003 where the coefficient is positive ( 0.756 and 0.714 respectively) and significant. On the other hand, the

Table 2. Gravity Estimation on Cross Section

\begin{tabular}{|c|c|c|c|c|c|c|c|c|c|}
\hline & 1995 & 1996 & 1997 & 1998 & 1999 & 2000 & 2001 & 2002 & 2003 \\
\hline $\ln G D P$ & $0.552^{* *}$ & $0.585^{* * *}$ & $0.637^{* * *}$ & $0.703^{* * *}$ & $0.473^{* * * *}$ & $0.491^{* * *}$ & $0.461^{* * * *}$ & $0.411^{* * *}$ & $0.456^{* *}$ \\
\hline source & $(4.72)$ & (6.19) & (6.45) & (6.91) & (3.59) & (4.31) & (3.65) & (3.33) & (3.13) \\
\hline \multirow{2}{*}{$\begin{array}{c}\ln G D P \\
\text { host }\end{array}$} & 0.066 & 0.130 & 0.210 & 0.380 & -0.130 & -0.200 & -0.507 & $-1.572^{* * *}$ & -0.373 \\
\hline & $(0.49)$ & (1.02) & (1.34) & (1.96) & $(-0.58)$ & $(-0.99)$ & $(-1.63)$ & $(-2.46)$ & $(-0.52)$ \\
\hline \multirow{2}{*}{$\begin{array}{c}\ln P G D P \\
\text { source }\end{array}$} & $0.707^{*}$ & $0.825^{* * *}$ & $0.717^{* * *}$ & $0.713^{* * *}$ & $0.763^{* * *}$ & $0.618^{* * *}$ & $0.645^{* * *}$ & $0.812^{* * *}$ & $0.839^{* * *}$ \\
\hline & (7.67) & $(9.25)$ & (7.65) & $(5.83)$ & $(5.71)$ & $(4.50)$ & (4.51) & (6.10) & $(6.50)$ \\
\hline \multirow{2}{*}{$\begin{array}{c}\ln P G D P \\
\text { host }\end{array}$} & 0.053 & $0.192^{* * *}$ & 0.042 & $0.199^{* *}$ & 0.022 & $0.079^{* * *}$ & -0.110 & 0.142 & $0.281^{* *}$ \\
\hline & $(0.57)$ & $(2.21)$ & $(0.43)$ & (1.99) & $(0.15)$ & $(0.58)$ & $(-0.76)$ & (0.94) & (1.96) \\
\hline \multirow{2}{*}{$\begin{array}{c}\ln O P E N \\
\text { host }\end{array}$} & $0.733^{* * *}$ & $0.642^{* * *}$ & $0.637^{* * *}$ & $0.421^{* * *}$ & $0.804^{* * *}$ & $0.860^{* * *}$ & $1.155^{* * *}$ & $1.802^{* * *}$ & 0.759 \\
\hline & $(6.15)$ & (6.28) & (4.41) & $(2.45)$ & (3.91) & (4.69) & $(4.37)$ & (3.49) & (1.38) \\
\hline \multirow{2}{*}{$\ln D I S T$} & $-1.015^{*}$ & $-0.888^{* * *}$ & $-0.988^{* * *}$ & $-1.020^{* * *}$ & $-0.745^{* * *}$ & & 15 & $-0.625^{* * *}$ & $-c$ \\
\hline & $(-4.42)$ & $(-4.53)$ & $(-4.83)$ & $(-4.94)$ & $(-2.95)$ & $(-1.63)$ & $(-1.49)$ & $(-2.48)$ & $(-1.60)$ \\
\hline \multirow{2}{*}{ BORDER } & 0.113 & 0.246 & 0.086 & 0.144 & 0.257 & 0.303 & 0.218 & $0.519^{* * *}$ & $0.415^{* * *}$ \\
\hline & $(0.62)$ & (1.32) & $(0.46)$ & (0.79) & (1.20) & (1.11) & $(0.88)$ & (2.32) & $(2.00)$ \\
\hline \multirow{2}{*}{ Language } & $0.476^{* *}$ & $0.257^{* * *}$ & $0.491^{* * *}$ & $0.326^{*}$ & 0.253 & $0.564^{* * *}$ & 0.357 & -0.078 & 0.325 \\
\hline & (3.18) & (2.11) & $(2.17)$ & (1.73) & $(0.85)$ & (3.17) & (1.43) & $(-0.27)$ & (1.18) \\
\hline \multirow{2}{*}{$\begin{array}{c}\text { Intra } \\
\text { ASEAN5 }\end{array}$} & -0.288 & 0.006 & -0.044 & 0.057 & -0.158 & -0.133 & -0.031 & $0.756^{* * *}$ & $0.714^{* * *}$ \\
\hline & $(-1.42)$ & (0.04) & $(-0.26)$ & $(0.27)$ & $(-0.66)$ & $(-0.57)$ & $(-0.10)$ & (2.13) & (2.87) \\
\hline \multirow{2}{*}{$\begin{array}{l}\text { ASEAN5 } \\
\text { to new }\end{array}$} & $0.633^{* * *}$ & $0.955^{* * *}$ & $0.874^{* * *}$ & $0.795^{* * *}$ & $0.515^{* * *}$ & $0.715^{* * *}$ & $0.646^{* * *}$ & $0.492^{* * *}$ & $0.788^{* * *}$ \\
\hline & (3.51) & $(5.44)$ & $(4.74)$ & $(4.40)$ & $(2.40)$ & $(3.33)$ & (3.28) & $(2.54)$ & (4.14) \\
\hline \multirow{2}{*}{ constant } & $-12.73^{* * *}$ & $-14.28^{* * * *}$ & $-14.40^{* * * *}$ & $-15.119^{* * *}$ & $-11.783^{* * *}$ & $-12.80^{* * * *}$ & $-11.84^{* * *}$ & $-7.594^{* * *}$ & -11.335 \\
\hline & $(-8.35)$ & $(-10.45)$ & $(-9.35)$ & $(-10.07)$ & $(-6.28)$ & $(-8.82)$ & $(-6.58)$ & $(-3.02)$ & $(-3.88)$ \\
\hline \multirow{2}{*}{$\begin{array}{c}\text { observa- } \\
\text { tion } \\
R^{2}\end{array}$} & 153 & 154 & 149 & 141 & 139 & 135 & 126 & 135 & 133 \\
\hline & 0.6346 & 0.6514 & 0.6131 & 0.6273 & 0.5211 & 0.5697 & 0.5398 & 0.5045 & 0.4705 \\
\hline
\end{tabular}

Notes: $* * * * *$ and $*$ denote $1 \%, 5 \%$ and $10 \%$ level of significance, respectively. The figures in parentheses are the $t$-statistics 
dummy for intra-regional FDI to ASEAN4 are all positive and significant for all years.

\section{B. Effects of Extra-ASEAN-FDI}

Table 3 presents the effects of extra-ASEAN FDI where the estimated coefficients are quite similar with the bench mark as in Table 1. There are positive FDI flows from European investors, but less investment from Australia and New Zealand, East Asian and North America. However, the estimated coefficient dummies for extra regional FDI to new members of ASEAN are all negative. Since the results are not really convincing, further estimation which includes dummies between Japan and US to ASEAN members are considered and the results reports in Table 4.

Column (1) introduces bilateral dummies between Japan and US with ASEAN5

Table 3. Results of Fixed Effect Estimation: from Regional Source Countries to ASEAN members

\begin{tabular}{|c|c|c|c|c|}
\hline \multirow[b]{3}{*}{$\ln G D P$ source } & \multicolumn{2}{|c|}{ (1) } & \multicolumn{2}{|c|}{$(2)$} \\
\hline & \multicolumn{2}{|r|}{$t$-statistics } & \multicolumn{2}{|r|}{$t$-statistics } \\
\hline & $0.402^{* * *}$ & $(9.59)$ & $0.542^{* * *}$ & $(12.79)$ \\
\hline $\ln G D P$ host & 0.062 & $(0.94)$ & 0.052 & $(0.80)$ \\
\hline $\ln P G D P$ source & $0.643^{* * *}$ & $(16.11)$ & $0.649^{* * *}$ & $(16.08)$ \\
\hline $\ln P G D P$ host & $0.141^{* * *}$ & $(3.70)$ & $0.135^{* * *}$ & $(3.61)$ \\
\hline $\ln O P E N$ host & $0.567^{* * *}$ & $(9.52)$ & $0.456^{* * *}$ & (7.77) \\
\hline $\ln D I S T$ & $-0.945^{* * *}$ & $(-10.61)$ & $-0.930^{* * *}$ & $(-10.33)$ \\
\hline BORDER & 0.067 & $(0.91)$ & $0.140^{* *}$ & $(1.94)$ \\
\hline Language & $0.363^{* * *}$ & $(4.31)$ & $0.395^{* * *}$ & $(5.26)$ \\
\hline East Asia to ASEAN5 & $-0.142^{* * *}$ & $(2.41)$ & & \\
\hline AUNZ to ASEAN5 & $-0.553^{* * *}$ & $(-6.31)$ & & \\
\hline EU to ASEAN5 & $0.229^{* * *}$ & $(2.41)$ & & \\
\hline North America to ASEAN5 & 0.043 & $(0.33)$ & & \\
\hline East Asia to ASEAN new & & & $-0.309^{* * *}$ & $(-4.51)$ \\
\hline AUNZ to ASEAN new & & & -0.138 & $(-1.33)$ \\
\hline EU to ASEAN new & & & -0.905 & $(-0.92)$ \\
\hline North America to ASEAN new & & & $-0.496^{* * *}$ & $(-5.45)$ \\
\hline constant & $-9.428^{* * *}$ & $(-15.67)$ & $-9.807^{* * *}$ & $(-21.06)$ \\
\hline Time effects & $\mathrm{F}(8,124$ & $8.19^{* * *}$ & $\mathrm{~F}(8,124$ & $=7.73^{* * *}$ \\
\hline Bilateral effects & $\mathrm{F}(4,1244$ & $20.12^{* * *}$ & $\mathrm{~F}(4,124$ & $=10.97$ \\
\hline observation & & & & \\
\hline$R^{2}$ & & & 0.5 & \\
\hline
\end{tabular}

Notes: $* * *, * *$ and $*$ denote $1 \%, 5 \%$ and $10 \%$ level of significance, respectively. The figures in parentheses are the $t$-statistics 
and new members. The results reveal that both Japan and the US favour investment in the original ASEAN countries rather than new members. Refined estimation in column (2) shows that Singapore, Malaysia and Thailand are among the top destination of Japanese and the USA FDI flows in ASEAN. All gravity variable coefficients are significant and have the correct sign with the exception of border, which is positive but insignificant. The regression includes time effects and bilateral effects which are also highly significant.

Table 4. Results of Fixed Effect Estimation: from Japan and the USA to ASEAN Members

\begin{tabular}{|c|c|c|c|c|}
\hline \multirow[b]{3}{*}{$\ln G D P$ source } & \multicolumn{2}{|c|}{ (1) } & \multicolumn{2}{|c|}{ (2) } \\
\hline & & $t$-statistics & & $t$-statistics \\
\hline & $0.437^{* * *}$ & (8.19) & $0.383^{* * *}$ & $(8.76)$ \\
\hline $\ln G D P$ host & 0.0567 & $(0.87)$ & 0.059 & $(0.89)$ \\
\hline $\ln P G D P$ source & $0.628^{* * *}$ & $(15.50)$ & $0.609^{* * *}$ & $(15.21)$ \\
\hline $\ln P G D P$ host & $0.141^{* * *}$ & $(3.71)$ & $0.133^{* * *}$ & $(3.42)$ \\
\hline $\ln O P E N$ host & $0.499^{* * *}$ & $(8.83)$ & $0.509^{* * *}$ & (8.97) \\
\hline $\ln D I S T$ & $-0.960^{* * *}$ & $(-11.33)$ & $-0.917^{* * *}$ & $(-11.37)$ \\
\hline BORDER & 0.1004 & $(1.48)$ & 0.105 & $(1.47)$ \\
\hline Language & $0.344^{* * *}$ & $(4.35)$ & $0.393^{* * *}$ & $(4.40)$ \\
\hline Jpn_ASEAN5 & $0.374^{* * *}$ & (3.89) & & \\
\hline Jpn_ASEAN new & $-0.385^{* * *}$ & $(-3.06)$ & & \\
\hline US_ASEAN5 & $0.665^{* * *}$ & $(6.35)$ & & \\
\hline US_ASEAN new & -0.152 & $(-1.23)$ & & \\
\hline Jpn_sgp & & & $0.979^{* * *}$ & $(13.84)$ \\
\hline Jpn_mal & & & $0.467^{* * *}$ & (4.39) \\
\hline Jpn_tha & & & $0.386^{* * *}$ & (3.94) \\
\hline Jpn_ind & & & 0.187 & (1.18) \\
\hline Jpn_phl & & & 0.979 & $(0.41)$ \\
\hline US_sgp & & & $1.008^{* * *}$ & $(8.95)$ \\
\hline US_mal & & & $0.829^{* * *}$ & $(6.41)$ \\
\hline US tha & & & $0.819^{* * *}$ & $(6.22)$ \\
\hline US_ind & & & $0.637^{* * *}$ & $(4.03)$ \\
\hline US_phl & & & 0.280 & (1.64) \\
\hline constant & $-9.000^{* * *}$ & $(-14.97)$ & $-8.594^{* * *}$ & $(-16.25)$ \\
\hline Time effects & $F(8,12$ & $7.86^{* * *}$ & $F(8,12$ & $7.41^{* * *}$ \\
\hline Bilateral effects & $F(4,124$ & $1.89^{* * *}$ & $F(10,12$ & $27.38^{* * *}$ \\
\hline observation & & & & \\
\hline$R^{2}$ & & & & \\
\hline
\end{tabular}




\section{Summary, Conclusion and Further Research}

The key focus of this study is to find the relationship between REI and FDI with reference to ASEAN members after the implementation of free trade agreement 1992. This study purposely fully utilized the ASEAN FDI database published by ASEAN Secretariat (2004). The implementation of AFTA in 1992, which brought along investment packages such as the ASEAN Industrial Scheme in 1996 and the ASEAN Investment Area in 1998, benefited the new members in terms of FDI receipts from ASEAN members since they have to do domestic reform to gain benefit from AIA and AICO.

The gravity estimations reveal that factors such as market size, income per capita for both source and host countries are positively related with FDI in both panel and cross section analysis owing to greater market opportunities for investors. There is also evidence of trade-FDI is complementary which suggesting that the policy reform after the implementation of AFTA may contribute increasing in both trade and FDI in ASEAN region. There are mainly two effects considered in this study: intra-ASEAN FDI and extra-ASEAN FDI. The first effect shows that the original ASEAN members invest less in each other. However, they invest more to the other ASEAN members such as Brunei, Laos, Myanmar and Vietnam. However, the effect of ASEAN on extra-ASEAN FDI found that regional economic groups such as North America, East Asia, and Australia-New Zealand except European countries invest less in ASEAN countries. The 1997 financial crisis may be one of the reasons to cause investments to divert to other regional groups or newly emerging countries like China and India. Moreover, the 2001 global investment downturn also delayed the process of ASEAN's recovery from the financial crisis. Further investigation also found that, even though as a regional economic group East Asia and North America have been reducing their investment into ASEAN, Japan and the USA still maintained their investment level in these countries. However, they invest more in the original ASEAN, which is known to consist of newly emerging industrial countries, rather than in Brunei and the new ASEAN. Moreover, investors can still market their products to the new ASEANusing the original ASEAN as a base for their headquarters and assembly operations before exporting to all ASEAN countries with a minimum expenditure on tariffs.

In conclusion, regional economic integration can be a medium to attract more FDI to the countries via the introduction of more attractive investment packages in the free trade agreements. However, it is also up to the individual country to further 
liberalise their national investment policy and provide competitive and attractive investment environments.

\section{Acknowledgements}

The author would like to thank an anonymous referee, the managing editor of this journal for their comments and suggestions for improvement on this paper. Without implicating them, she bears the responsibility of any remaining deficiencies.

Received 4 December 2008, Revised 10 June 2009, Accepted 12 June 2009

\section{References}

Aitken, B. and Harrison, A.(1999), "Do Domestic Firms Benefit from Direct Foreign Investment? Evidence from Venezuela", American Economic Review, 89(3), pp. 60518.

Altomonte, C.(1998), "FDI in the CEEC's and the Theory of Real Options: an Empirical Assessment", Discussion Paper 76/1998 LICOS Centre for Transition Economics.

Altomonte, C.(2004), "Regional Economic Integration and the Location of Multinational Enterprises", Centro di Ricerca sui Processi di Innovazione e Internazionalizzazione.

Anderson, J. E.(1979), "A Theoretical Foundation for the Gravity Equation”, American Economic Review, 69(1), pp. 106-116.

Aminian, N; Fung, K.C. and Iizaka, H.(2007), "Foreign Direct Investment, Intra-regional Trade and Production Sharing in East Asia", RIETI Discussion Paper Series 07-E064.

ASEAN Secretariat website: http://www.aseansec.org.

ASEAN Secretariat(2004), ASEAN Statistical Yearbook 2004.

Balassa, B.(1961), The Theory of Economic Integration, London, Allen \& Unwin.

Balassa, B.(1967), "Trade Creation and Trade Diversion in the European Common Market", The Economic Journal, 77, London.

Balasubramanyam, V. N., Sapsford, D. and Griffiths, D.(2002), "Regional Integration Agreements and Foreign Direct Investment: Theory and Preliminary Evidence", The Manchester school, 70(3), pp. 460-482.

Bende-Nabende. A., Ford, J. and Slater, J.(2001), "FDI, Regional Economic Integration and Endogenous Growth: Some Evidence from Southeast Asia", Pacific Economic Review, 6(3), pp. 383-99.

Bevan, A., Estrin, S. and Grabbe, H.(2001), The Impact of EU Accession Prospects on FDI Inflows to Central and Eastern Europe, Policy Paper 06/01.

Billington, S.(1999), “The Location of Foreign Direct Investment: an Empirical 
Analysis", Applied Economics, 31(1), p. 65-6.

Blalock, G.(2001), Technology from Foreign Direct Investment: Strategic Transfer through Supply Chains. Mimeo, UC Berkeley.

Blomström, M. and Kokko, A.(1997), Regional Integration and Foreign Direct Investment, Working Paper Series in Economics and Finance No. 172.

Blomstrom, M., Kokko, A. and Steven G, S.(1998), Regional Economic Integration and FDI: The North American experience, Working paper series in Economics And Finance, No. 269, 25.

Bloom, N., Schankerman, M. and Van Reenen, J.(2005), Identifying Technology Spillovers and Product Market Rivalry, CEPR Discussion Paper 4912.

Boreinsztein, E., De-Gregorio, J. and Lee, J. W.(1998), "How does Foreign Direct Investment Affect Economic Growth?", Journal of International Economics, 45(1), pp. 115-35.

Brenton, P.(1999), Trade and Investment in Europe: the Impact of the Next Enlargement, Brussels: Centre for European Policy Studies, Brussels.

Buch, C. M. and Piazolo, D.(2001), "Capital and Trade Flows in Europe and the Impact of Enlargement”, Economic Systems, 25, pp. 183-214.

Buch, C. M., Kleinert, J. and Toubal, F.(2003), The Distance Puzzle: on the Interpretation of the Distance Coefficient in Gravity Equations, Kiel Working Papers 1159, Kiel Institute for the World Economy.

Buch, C. M., Robert, M., Kokta, R. M. and Piazolo, D.(2003), "Foreign Direct Investment in Europe: is there Redirection from the South to the East?", Journal of Comparative Economics, 31, pp. 94-109.

Campos, N. F. and Kinoshita, Y.(2002), "Foreign Direct Investment as Technology Transferred: Some Panel Evidence from Transition Economies", Manchester School, University of Manchester, 70(3), pp. 398-419.

Carstensen, K. and Toubal, F.(2004), "Foreign Direct Investment in Central and Eastern European Countries: a Dynamic Panel Analysis", Journal of Comparative Economics, 32(1), pp. 3-22.

Chen, C.(1997), Provincial Characteristics and Foreign Direct Investment Location Decision within China, Chinese Economy Research Unit Working Paper No. 97/16, University of Adelaide.

Cheng, I-H. and J. Wall, H. J.(2005), "Controlling for Heterogeneity in Gravity Models of Trade and Integration", Federal Reserve Bank of St. Louis Review, 87(1), pp. 49-63.

Clausing, K. A. and Dorobantu, C. L.(2005), "Re-entering Europe: does European Union Candidacy Boost Foreign Direct Investment?", Economics of Transition, 13(1), pp. 77-103.

Donnenfeld, S.(2003), "Regional Blocs and Foreign Direct Investment", Review of International Economics, 11(5), pp. 770-788.

Dowling M. and Cheang C. T.(2000), "Shifting Comparative Advantage in Asia: New Tests of the 'Flying Geese' Model”, Journal of Asian Economics, 11, pp. 443-63.

Dowling, M. and Ray, D.(2000), "The Structure and Composition of International Trade 
in Asia: Historical Trends and Future Prospects", Journal of Asian Economics, 11, pp. 301-318.

Drabek, Z. and Payne, W.(1999), The Impact of Transparency on Foreign Direct Investment, Staff Working Paper, EAR 99-02 (Geneva: World Trade Organization).

Dunning, J.(1997), "The European Internal Market Program and Inbound Foreign Direct Investment", Journal of Common Market Studies, 35(2).

Eaton, J. and Tamura, A.(1996), Japanese and U.S. Exports and Investment as Conduits of Growth, NBER Working Paper No. 5457, Cambridge, Mass.: National Bureau of Economic Research.

Egger, P. and Pfaffermayr, M.(2002), The Pure Effects of European Integration on IntraEU Core and Periphery Trade, Working papers in Economics, 25, Institute of Economic theory, Economic Policy and Economic History, University of Innsbruck.

Egger, P. and Pfaffermayr, M.(2003), "The Proper Econometric Specification of the Gravity Equation: a Three-Way Model With Bilateral Interaction Effects", Empirical Economics, 28(3), pp. 571-80.

Eichengreen, B. and Frankel, J. A.(1995), "Economic Regionalism: Evidence from Two 20th Century Episodes", North America Journal of Economics and Finance, 6(2), pp. 89-106.

Ekholm, K.(1998), "Proximity Advantages, Scale Economies, and the Location of Production", in Braunerhjelm \& Ekholm(editors), The Geography of Multinational Firms, Boston: Kluwer Academic Publishers.

El-Agraa, A. M.(1997), Economic Integration World-Wide, Macmillan Press, London.

Ethier, W. J.(1998), “The New Regionalism”, Journal of Political Economy, 106, pp. 1214-1245.

Haskel, J., Pereira, S. and Slaughter, M.(2002), Does Inward Foreign Direct Investment Boost the Productivity of Domestic Firms? NBER Working Paper 8724.

Heinrich, J. and Konan, D. E.(2000), "Foreign Direct Investment and Host-Country Trading Blocs", Journal of Economic Integration, 5, 2000, pp. 565-84.

Helpman, E. and Krugman, P. R.(1985), Market Structure and Foreign Trade, MIT Press.

Helpman, E.(1984), "Multinational Corporations and Trade Structure", Review of Economic Studies, 92(3), pp. 451-71.

Hobday, M.(1995), "East Asian Latecomer Firms: Learning the Technology of Electronics", World Development, 23, pp. 1171-93.

Hsiao, C.(1986), Analysis of Panel Data, Econometric Society Monographs, Cambridge, New York and Sydney, Cambridge University Press.

Hubert P. J. and Phanindra V. W.(2004), "Determinants of Foreign Direct Investment: Empirical Evidence from EU Accession Candidates", Applied Economics, 36, pp. 505-509.

Hubert, F. and Pain, N.(2002), "Fiscal Incentive, European Integration and the Location of Foreign Direct Investment", The Manchester School, 70(3).

Jaumotte, F.(2004), "Foreign Direct Investment and Regional Trade Agreements: the Market Size Effect Revisited", International Monetary Fund, WP/04/206. 
Keller, W. and Yeaple, S.(2003), Multinational Enterprises, International Trade, and Productivity Growth: Firm-Level Evidence from the United States, NBER No. 9504.

Kindleberger, C. P.(1966), "European Integration and the International Corporation", Columbia Journal of World Business, 1, pp. 65-73.

Kinoshita, Y. and Campos, N. F.(2003), Why does FDI Go Where it Goes? New Evidence from the Transitional Economies, CEPR Discussion Paper No. 3984.

Kohlagen, S.(1977), Exchange Rate Changes, Profitability and Direct Foreign Investment, Southern Economic Journal, 44, p. 43-52.

Kokko, A.(1994), "Technology, Market Characteristics, and Spillovers", Journal of Development Economics, 43(2), pp. 279-293.

Kugler, M.(2000a), Externalities from Foreign Direct Investment: the Sectoral Pattern of Spillovers and Linkages, Discussion Papers on Economics and Econometrics, University of Southampton, Southampton.

Kugler, M.(2000b), The Diffusion of Externalities from Foreign Direct Investment: Theory Ahead of Measurement, Discussion Paper on Economics and Econometrics, University of Southampton, Southampton.

Kugler, M(2001), The Sectoral Diffusion of Spillovers from Foreign Direct Investment, Mimeo, University of Southampton, August.

Kugler, M(2006), "Spillover from Foreign Direct Investment: within or between Industries?", Journal of Development Economics, 80(2), pp. 444-477.

Lall, S.(1996), Learning from the Asian Tigers, Basingstoke: Macmillan.

Manaenkov, D.(2000), What Determines the Region of Location of an FDI Project? an Empirical Assessment, Working Paper No. BSP/00/036E, Moscow, New Economic School.

Marchant, M. A, Cornell, D. N and Koo, W.(2002), "International Trade and Foreign Direct Investment: Substitute or Complements?", Journal of Agrocultural Applied Economics, 2, pp. 289-302.

Markusen, A. R., Rutherford, T. F and Tarr, D.(2000), Foreign Direct Investments in Services and the Domestic Market for Expertise, NBER Working Papers 7700, National Bureau of Economic Research, Inc.

Markusen, J. and Maskus, K.(2001), General Equilibrium Approach to the Multinational Firm: a Review of Theory and Evidence, NBER Working Paper No. 8334, National Bureau of Economic Research, Cambridge, MA.

Markusen, J. and Venables, A.(1998), "Multinational Firms and the New Trade Theory", Journal of International Economics, 46, pp. 183-204.

Mauro, F. D.(2000), The Impact of Economic Integration on FDI and Exports: a Gravity Approach, Working Document No. 156, Centre For European Policy Studies.

Mauro, F. D.(2001), Economic Integration between the EU and the CEECs: a Sectoral Study, Discussion Paper 105/2001.

Mirza, H. and Giroud, A.(2004), "Regional Integration and Benefits from Foreign Direct Investment in ASEAN Economies: the Case of Viet Nam", Asian Development Review, 21(1), pp. 66-98. 
Mirza, H.(2002), Regionalization, FDI and Poverty Reduction: Lessons from Other ASEAN Countries, Paper Prepared for the DfID Workshop on Globalization and Poverty in Vietnam, Hanoi, 23-24th September 2002.

Montes, M. F.(1997), "Direct Foreign Investment and Technology Transfer in ASEAN", Economic Bulletin, 14(2).

Motta, M. and Norman, G.(1996), "Does Economic Integration Cause Foreign Direct Investment?", International Economic Review, 37(4).

Neary, J. P.(2002), "Foreign Direct Investment and Single Market", The Manchester school, 70(3), pp. 291-314.

Noorbakhsh, F. and Paloni, A.(2001), "Human Capital and FDI Inflows to Developing Countries: New Empirical Evidence", World Development, 29(9), pp.1593-610.

Pain, N. and Lansbury, M.(1997), "Regional Economic Integration and Foreign Direct Investment: the Case of German Investment in Europe", National Institute Economic Review, 160, pp. 87-99.

Robson, P.(1993), "The New Regionalism and Developing Countries", Journal of Common Market Studies, 31(3), pp. 329-348.

Smarzynska, B.(2004), "Does Foreign Direct Investment Increase the Productivity of Domestic Firms?", in Search of Spillovers through Backward Linkages, American Economic Review, 94(3), pp. 605-627.

Stein, E., Ernesto and Daude, C.(2001), Institutions, Integration, and the Location of FDI, Inter American Development Bank, Washington DC. Mimeo.

Thorton, J. and Goglio, A.(2002), "Regional Bias and Intra-regional Trade in Southeast Asia", Applied Economic Letter, 9, pp. 205-208.

Varian, H.(1995), "Entry and Cost Reduction", Japan and the World Economy, 7(4), pp. 399-410.

Viner, J.(1950), The Custom Union Issue, New York.

Waldkirch, A.(2003), “The 'New Regionalism' and FDI: the Case of Mexico", Journal International Trade and Economic development, 12(12), pp. 151-184.

Yeyati L., E., Stein, E. and Daude, C.(2002), Regional Integration and the Locational of FDI, Inter American Development Bank, Washington DC. Mimeo. 